\section{THE MENHADEN}

The Menhaden; being a History of the Fish. By G. Brown Goode. With an Account of the Agricultural Uses of Fish. By W. O. Atwater. (New York: Orange Judd Company, 1880.)

$\mathrm{N}$ money value the American menhaden ranks fourth 1 in the list of the fishes of the United States. First comes the cod, sccondly the salmon, thirdly the mackerel, and then the menhaden. In absolute pounds' weight caught it would seem to come first of all, upwards of 460 millions of pounds' weight having been taken in 1876 , whereas there was considerably less than half this weight of cod taken in that year, and all the salmon and mackerel taken if weighed together would not amount to much more than one-sixth of the weight. As its money valuc must depend on its economic value, it may be as well at once to briefly hint at its uses. As a table fish it is in favour in many parts of the United States, when perfectly fresh being considered superior in flavour to most of the common shorc fishes. In the Washington fish market, when in season, they meet with a ready sale. Large quantities are salted, and there is a great export of these to the West Indies, where they serve as food for the negroes upon the plantations. Immense numbers are preserved in oil and spices and sold as sardines. Goodale's extract of fish is made out of menhaden, and the qualities of this preparation arc testified to as bcing agrecable in flavour and decidedly nutritive as food for cattle. Menhaden scrap is a great success; sheep get rapidly fat on it. Hens, ducks, and turkeys prefer it to corn, and it need not be added that pigs grecdily devour it. For bait it is extensively used in the cod and mackerel fisheries in New England and the British Provinces. Its popularity is no doubt chiefly due to the easc with which it may' be obtained in quantity. As an article of commerce menhaden bait, it will be remembered, came under the considcration of the Halifax Commission of 1877 ; but perhaps even a greater future is open to the menhaden fisheries by the recently-established manufacture of oil and guano from these fish. The State of Maine claims to have been the first to discover its value, and now large factories turn out immense quantities of these materials. In 1874 from 50,000 to 75,000 gallons of oil was turned out from the Maine Works. The manufacture is simple in the extreme, consisting of three processes: boiling the fish, pressing and clarifying the expressed oil. The final operation is pumping it into immense bleaching tanks, where it becomes whiter and clearer in the rays of the sun. When well refined the oil is light-coloured, swcet, and of prime quality. The uscs of this oil are manifold. It is chiefly employed, we are told, as a substitute for the more costly and popular oils, and to adulterate them. It is sold largely to tanneries for currying leather. The principal market for it is in I3oston and New York, but considcrable quantitics are shipped to London, Liverpool, and Havre. IBut menhaden has still further uses. So far back in American history as $162 \mathrm{I}$ we read that the Pljmouth colonists learnt from an old Indian that they should use these fish as manure on their ground; and onc Fidward Johnson, writing in 1652 , says, "But the Lord is pleased to provide for them [the New England colonists] great storc of fish in the spring timc. Many thousands of these they used to put under their Indian corn, which they plant in rills five foot asunder." Now as a result of the profitable utilisation of the menhaden for the manufacture of oil, the use of the whole fish as a fertiliser has gradually and almost entirely ceased, and the refuse from which the oil bas been expressed is used instead. This is known as "fish-scrap" and "fish guano." In a wheat.growing country like North America the importance of the subject of artificial manures is great, and we quote from Prof. Cook's, of New Jersey, report to the State Board of Agriculture as follows: "Those who have tried a mixture of this fish guano with barn-yard manure and a little lime, say that it is supcrior to any guano in the market. When applied on corn the crop is considered as certain. The value of fish as manure is due mainly to the presence in it of nitrogen and phosphoric acid. The crops most assisted by fish manures arc such as grass, grain, and corn, while leguminous crops, like clover, beans, and peas, are more benefited by mineral manures."

The above is but a brief résumé of one portion of Messrs. Goode and Atwater's interesting work, the title of which is quoted above. Their history was prepared for the Fifth Annual Report of the Commissioner of Fisheries for 1877. As reprinted, it forms an octavo volume of 540 pages and 30 plates.

The menliaden (Clupca menhaden of Mitchell) is, when adult, a most beautiful fish ; its colour is pearly opalescent; each scale has all the bbiauty of a fine pearl, and the reflections from the mailed side of a fish just taken from the water are superb; the scales of the back and top of the head are of a purplish hue. Its importance to the States may be compared to the importance of the herring to Northern Europe. It is to be found at the same period during the year in the coast waters of all the Atlantic States from Maine to Florida. A surface temperature of about $51^{\circ}$ is necessary for its appearance in waters near the shores. Its food is apparently for the most part minute algæ. The geographical range of the species, the arrival and departure of the "schools," the migration question, the peculiar movements of the "schools" of menhaden, are all subjects discussed at great length in this report, and from it many facts of great value to those interested in our own shore-fisheries are to be lcarnt.

The strange and unaccountable absence of the menhaden last year from the waters of Cape Cod are briefly alluded to in the Introduction. This absence was disas. trous to many, and proved by a sad experience that the harvest of the sea will sometimes fail. The oil and guano factorics lost a year's wor: ; the factory hands and steamcr's crew were entirely thrown out of employment ; those were all on hand to begin woris on June $I$, and kept working, in the hope that the fish would "strike," until late in August. When they at last gave up all hope it was too late to engage in any other occupation to make money so carry them over the winter. This absence of the fish north of the Cape did not appear to be compensated for by any remarkable abundance in southern New England, but a much larger number of fish were capturcd in these waters in 1879 , as so many more vessels went therc to fish. We hope soon to hear of a good season's fishing at Cape Cod, and we strongly recommend this important report on the menhaden to the reader's notice. 